\title{
Reading Indigenous and Mestizo Musical Instruments: The Negotiation of Political and Cultural Identities in Latin America
}

\section{ROBERT NEUSTADT}

In this essay, I am exploring diverse examples of indigenous and mestizo musical instruments in order to underscore the manner in which these instruments can help us to comprehend the political negotiation and location of culture. When I say "cultural location" I refer not only to geographical place, but also to a people's cultural values and traditions as situated within communities at particular moments in history. As for the "negotiation" of political identity, I am alluding to the process of transculturation through which different and sometimes contradictory elements of national, ethnic and/or social culture combine unevenly. Such negotiation is ongoing and subject to change; there exists no resolution. Strands of culture come to occupy dominant, prominent or subtle aspects of national identity through negotiation and these strands are visible in cultural representations such as music and dance. Although such processes of negotiation are inherent to all types of identity formation, they are particularly noteworthy in Latin American music because of the prevalence of cultural mestizaje.

Consider the example of Guatemala's national dance, the son. Ethnomusicologist Carlos Monsanto describes the dance as "a strange mixture of native rhythms and Spanish melodies" (“extrañas mezclas de ritmos autóctonos y melodías de corte español”). ${ }^{1}$ In a sense, this process of blending can be heard in much music in Latin America. Music in the Americas constitutes hybrid mixtures of Hispanic, indigenous and African cultures. The sounds of culture-representations and representers of identity-have been transformed through intense social, cultural and political negotiations. In this essay I will foreground the manner in which many of these negotiations have taken place on, with and through the mediation of musical instruments.

I should state from the outset that I am not an ethnomusicologist. I have not conducted fieldwork nor attempted to carry out organological studies of instruments. I am writing, rather, from a perspective of cultural studies, analyzing specific usages of musical instruments in order to trace threads of identity construction that are articulated within and between Indo- and Latin America. My analyses focus on exemplary cases in which musical instruments serve as platforms for the negotiation of indigenous, mestizo and national identities. My examples derive from an array of sources-from literary texts, such as Rigoberta Menchú's testimonial, to anthropological, ethnomusicological and videographic documentary materials from Costa Rica, Guatemala and Mexico. I analyze the commentaries of musicians themselves, and also the observations of scholars and social critics who contribute to the overall discourse on music and identity.

I primarily focus on "indigenous" instruments, such as marimbas, chirimías and Indian fiddles, emphasizing their hybrid or transcultural roots. These instruments reveal the process through which

1 Carlos Monsanto, “Guatemala a través de su marimba," Latin American Music Review 3, no. 1 (Spring-Summer 1982): 65. 


\section{Music and Politics Summer 2007}

indigenous and mestizo cultures have changed over time. The process of transcultural negotiation is particularly evident in the manner in which indigenous cultures have adapted European musical instruments, constructing, as it were, their own original instruments with which to express their culture. I conclude the essay by analyzing a group of recently invented mestizo instrumentsinnovations on the marimba-in order to highlight the continuation of the history of political negotiation at a different place in the transcultural cycle.

\section{Reading Marimbas: Instrumental Negotiations of Guatemalan National Identity}

Reading the manner in which scholars "read" pre-Colombian "music," can reveal as much about the scholars themselves as early indigenous music. Take, for example, the polemic about whether the marimba derives originally from Africa, pre-Hispanic Mesoamerica or Asia. ${ }^{2}$ Regardless of the relative strengths and weaknesses of the data for each theory, some writers approach the question with a preconceived nationalistic agenda to prove that the marimba was first "theirs.” Enrique Analéu Díaz asserts that some have gone so far as to falsify documents in their quest to "find" proof that the marimba has pre-Hispanic American roots in the region of what today is Guatemala: "Los afanes por demostrar un origen antiguo de la Marimba en Guatemala han llevado al extremo de falsificar documentos gráficos, o de dar opiniones sin ninguna base en la interpretación de ello" ("The zeal to demonstrate an ancient origin of the Marimba in Guatemala has been carried to the extreme point of falsifying graphic documents, or stating opinions without any analytical basis"). ${ }^{3}$ This urgency to claim the marimba's origin illustrates the ferocity with which Guatemalan identity has been negotiated through music across history. ${ }^{4}$

Let's consider two notorious cases from Guatemala that claim to prove that the marimba has Mayan roots. Both of these propositions have been disputed by a majority of scholars. My purpose here is not to enter the debate, nor to test the merits of these cases, but rather to read these narratives of origin in a way that will foreground the manner in which the image of the marimba gets stretched and pulled across history from its mythical origin to the present of national identity. Guatemalan folklorist, Marcial Armas Lara, writes in El renacimiento de la danza guatemalteca y el origen de la marimba (1964), that he personally saw a fragment of a pre-Colombian Mayan codex that clearly portrays a deity, or a Maya dressed as the deity, playing what he calls an "arm marimba," a marimba de brazo. According to Armas's extraordinary tale, he was blindfolded and brought to a remote area in May of 1958 by indigenous priests (sacerdotes) who showed him the ancient image. Armas explains that he faithfully copied the codex. Allegedly, after he finished duplicating the codex, his

2 The most credible theory holds that the marimba found its way to the Americas via African slaves. For an extensive study of the marimba and its history, including the controversy regarding its origin, see Lester Godínez, La marimba guatemalteca (Fondo de Cultura Económica, 2002). See also the classic study by Vida Chenoweth, The Marimbas of Guatemala (Lexington: U of Kentucky P, 1964).

3 Enrique Anléu Díaz, “Apuntes sobre el origen de la marimba,” Tradiciones de Guatemala 43 (1995): 184. Brief Spanish citations are followed by English translations throughout this essay. For long quotes, I have placed the English translation in the text, and placed the original Spanish citation in a footnote. All translations from Spanish to English are my own, unless otherwise stated.

4 For perspective on the intensity of the polemic surrounding the marimba, see the article "Guatemala a través de su marimba” by Carlos Monsanto. 
indigenous guides rolled the parchment, placed it inside of a bamboo canister, sealed it with dark wax and then assured the document that it will remain "in hiding," "estarás oculto para el mundo." ${ }^{5}$ The indigenous curators again blindfolded Armas and transported him far from the original text. Subsequently Armas reproduced his copy of the codex as proof of the Mayan origin of the marimba in his own book.

Notice the archetypal structure of Armas's story. In quest of the mysterious origin of the marimba, the blind seeker is led to a cave that harbors an image/drawing of a Maya playing marimba. Armas concludes that he has found the grail, he had discovered incontrovertible evidence that the marimba began in the area now known as Guatemala. He claims, in other words, that he discovered the origin of the marimba and by extension the origin of Guatemalan identity. Paradoxically, he has solved the mystery of the marimba's origin, and lost the original register: The original codex, constituting the proof of the marimba's Mayan origin, remains hidden in an unknown cave. Unable to prove the marimba's origin, Armas attempts to prove the veracity of his experience. His proof is a copy, his copy, which he offers as a representation of the marimba's origin. In his book, in other words, he publishes a copy of the copy that he rendered of a drawing of a Mayan God playing marimba. Or, perhaps the original codex depicts a Mayan holy man, dressed as a God, playing marimba? In this reading, Armas's proof of the marimba's origin consists of a published copy of his rendered copy of a codex (in other words, an image/copy) of a costumed man playing marimbaperforming in the image of a Mayan God.

Carlos R. Asturias G., another Guatemalan who has embraced the mission to find and prove the marimba's Mayan origins, fully supports Armas's account and defends him against what he dismisses as "trivial and unfounded" criticism. ${ }^{6}$ For Asturias, Don Marcial Armas, "a great patriot and folklorist," has simply been misunderstood and treated unfairly. "Con mis investigaciones" ("With my research"), asserts Asturias, "le di validez y credibilidad a su evidencia" ("I proved the validity of his evidence"). ${ }^{8}$ What is perhaps most remarkable about Asturias's published defense of Armas is the fact that Asturias never actually examined Armas's original copy. Asturias beseeches both God and the Armas family to loan him Don Marcial's original copy.

All of this evidence is intimately related to the origin and evolution of the true Mayan marimba. I hope that God will help me to bring this evidence together in one place, in homage to our Mayan ancestors. This is a petition to the relatives of Don Marcial Armas Lara, that they will loan us, in front of the press, the valuable copy of the codex that he made. ${ }^{9}$

In the meantime, Asturias contracted an artist (Sololateco Edgar Ordoñez) to re-produce another copy of the copy for his article. Asturias's proof then, is based on an artist's copy of Armas's

5 Marcial Armas Lara, El renacimiento de la danza guatemalteca y el origen de la marimba (Guatemala: Centro Editorial "José de Pineda Ibarra,” 1964), 105.

6 Asturias Gómez, Carlos Ramiro and César Pineda del Valle, eds., Antología de la marimba en America / La verdadera evolución de la marinbah maya (Guatemala: Artemis-Edinter, 1994), 105.

7 Ibid., 103.

8 Ibid.

9 Ibid., 106. "Todas estas evidencias están íntimamente relacionadas con el origen y evolución de la verdadera marimba Maya, evidencias que espero en Dios, me ayude a reunir en un solo lugar, como un homenaje a nuestros ancestros Mayas. Por este medio hago un llamado a los parientes de Don Marcial Armas Lara, para que ante la prensa nos presten la valiosa copia del códice que él hizo.” 
published copy of his copy of an alleged Maya codex of a Maya religious leader playing an (unknown) arm marimba as an invocation to a Maya deity.

Asturias also recurs to real archaeological iconographical evidence, especially a post classical polychromatic Mayan vase known as el vaso de Ratinlinxul in his effort to prove a Mayan origin for the marimba. In this case, the original evidence is somewhat more present than Armas's codex, although not in Guatemala. The piece was excavated in 1923 and taken to the University of Pennsylvania in Philadelphia where it has been exhibited (as object \#11701) since 1924. Asturias argues vehemently that this and other relics of Guatemalan patrimony should be immediately returned to Guatemala.

In contrast to Armas's codex, scholars can actually examine the original vase of Ratinlinxul. Interpreting the Ratinlinxul images (estimated to have been made between 1,000 and 1,100 of the Common Era), on the other hand, is by no means straightforward. In one figure, some see a dog, others see a jaguar, others see a hybrid "jog," and Asturias sees a "perro de la muerte” (death-dog). Some identify the collective scene as that of a merchant accompanied by a team of porters. Others argue that the vase depicts a dead man walking in a funeral procession. Such details provide fodder for endless debate. According to Asturias, one of these figures carries a marimba on his back. Others see no marimba but rather a jaguar skin covered throne cushion. ${ }^{10}$ No doubt that others will find other images within this image.

Asturias does not merely read the images to form his interpretation. To prove his interpretation, Asturias went so far as to construct the "instrument" he sees, an instrument he calls a "marinbah de caja” ("box marinbah”). His logic of argumentation, accordingly, transcends archaeological evidence. Asturias models his instrument on an (unclear) image from an ancient vase and offers the existence of his new instrument as proof of the marimba's Mayan roots. Moreover, he publishes a photograph of his instrument in his book, Verdadera evolución de la marinbah maya (1994) to fortify his argument. Tracing the evidence (a photograph of an instrument modeled from a contested ancient image on a vase [or more likely, from photographs of the images on this vase]) reveals more about Asturias's agenda than a true instrumental origin.

Even if we bracket off the enigmatic pre-Conquest origin of the marimba, this wooden idiophone has undergone an extraordinary transformation in Guatemalan history. The Spaniards prohibited the instrument because of the ritual importance it played in Mayan communities. The Indians reacted by hiding their instruments, constructing them clandestinely and playing marimbas in secret ceremonies. ${ }^{11}$ Centuries later, in 1978, the marimba was declared Guatemala's "National Instrument" (Congressional decree, 66-78). ${ }^{12}$ The 1978 law also declared October 17 as the "Día Nacional de la Marimba" ("National Marimba Day"). Subsequently, in 1999, the marimba became elevated to the even higher category of "símbolo nacional" (national symbol) (Congressional decree, 31-99), effectively placing the marimba on the level of the Guatemalan flag and the country's national anthem.

10 See photographs of the vase and interpretations of its images in: Justin Kerr's, "Reflections on the Ratinlinxul Vase and others of the same theme," on the Maya Vase Database: www.mayavase.com/jour/journey.html.

11 Wolfgang Dietrich, "La marimba: Lenguaje musical y secreto de la violencia política en Guatemala," América Latina Hoy 35 (203): 156.

12 The marimba is also declared the National Instrument of Costa Rica, although its prevalence is primarily in the region of Guanacaste (the northwestern section of the country). 
Article 2 of the 1999 law holds the Ministry of Education responsible for supporting marimba education in public and private schools, dedicating part of the budget to provide marimbas to official educational institutions. Article 3 requires that the Ministry of Culture and Sports organize marimba events every year in September so as to give the instrument its due respect as national symbol (during the celebrations of Guatemalan independence). By featuring the marimba on the calendar, in schools and in civic ceremonies as a national symbol, the Guatemalan government afforded the instrument a prestigious position and status. In the context of official culture the marimba occupies a central place in the image of Guatemalan national identity.

The marimba's transformation from prohibited indigenous instrument to revered national symbol underscores the presence of indigenous roots in contemporary Guatemalan culture. Yet this historical trajectory of the marimba should not be taken as a vindication for indigenous music and culture. The designation of the marimba as Guatemala's national instrument implies a ladino (mestizo), as opposed to indigenous national culture, according to Wolfgang Dietrich in his article, "La marimba: Lenguaje musical y secreto de la violencia política en Guatemala." ${ }^{13}$ In fact, the official proclamation of the marimba as national instrument took place at a time when the government of Guatemala was intensifying a series of long-term genocidal campaigns against Maya Indians. ${ }^{14}$ In Maya Achi: Marimba Music in Guatemala, Sergio Navarrete Pellicer informs that marimba players were often singled out and disappeared during the period known as "la violencia" ("the violence"). ${ }^{15}$ The Guatemalan government banned indigenous gatherings with music in 1981 for several years. ${ }^{16}$ This is a case of history repeating itself: by banning indigenous gatherings with music, the Guatemalan government essentially reinstated the policy set in place by the Spanish Colonial authorities.

To read the political implications that are embedded within the recognition of the marimba as the national instrument of Guatemala, it is necessary to take a closer look at the marimbas themselves. The indigenous "marimba de tecomates," called k'ojom in K'iche', is comprised of a single row of wooden keys that hang suspended over gourd resonators (tecomates). A single musician plays the instrument, usually in rituals, and produces relatively simple diatonic melodies and traditional rhythms. The marimbas played at official recognition ceremonies, on the other hand, were not traditional indigenous "marimbas de tecomates," but rather ladino-designed chromatic marimbas.

\section{Audio Example 1}

Accessible at: http://dx.doi.org/10.3998/mp.9460447.0001.202

Description: An example of Tomás Canil playing "Sones de cofradía" on a marimba de tecomates in Chichicastenango, Guatemala. Track 9 of the CD, ORIGENES: RESONANCIAS DEL MUNDO MAYA (Guatemala: Amigos del País, 1999). Field recording by Samuel Franco, produced by Dieter Lehnhoff.

13 The term ladino means mestizo in Guatemala. Ladino is an ethnic, social and often socioeconomic marker, essentially signifying a mixed blood individual. In general, ladinos consider themselves to be white Hispanics. Ladinos identify themselves by underscoring the fact that they are not Indians. In some cases, nevertheless, ladino refers to an indigenous-born person who no longer lives by the conventions of traditional indigenous culture.

14 Dietrich, "La marimba," 162.

15 Sergio Navarrete Pellicer, Maya Achi Marimba Music in Guatemala (Philadelphia: Temple UP, 2005$), 24$.

16 Ibid. 

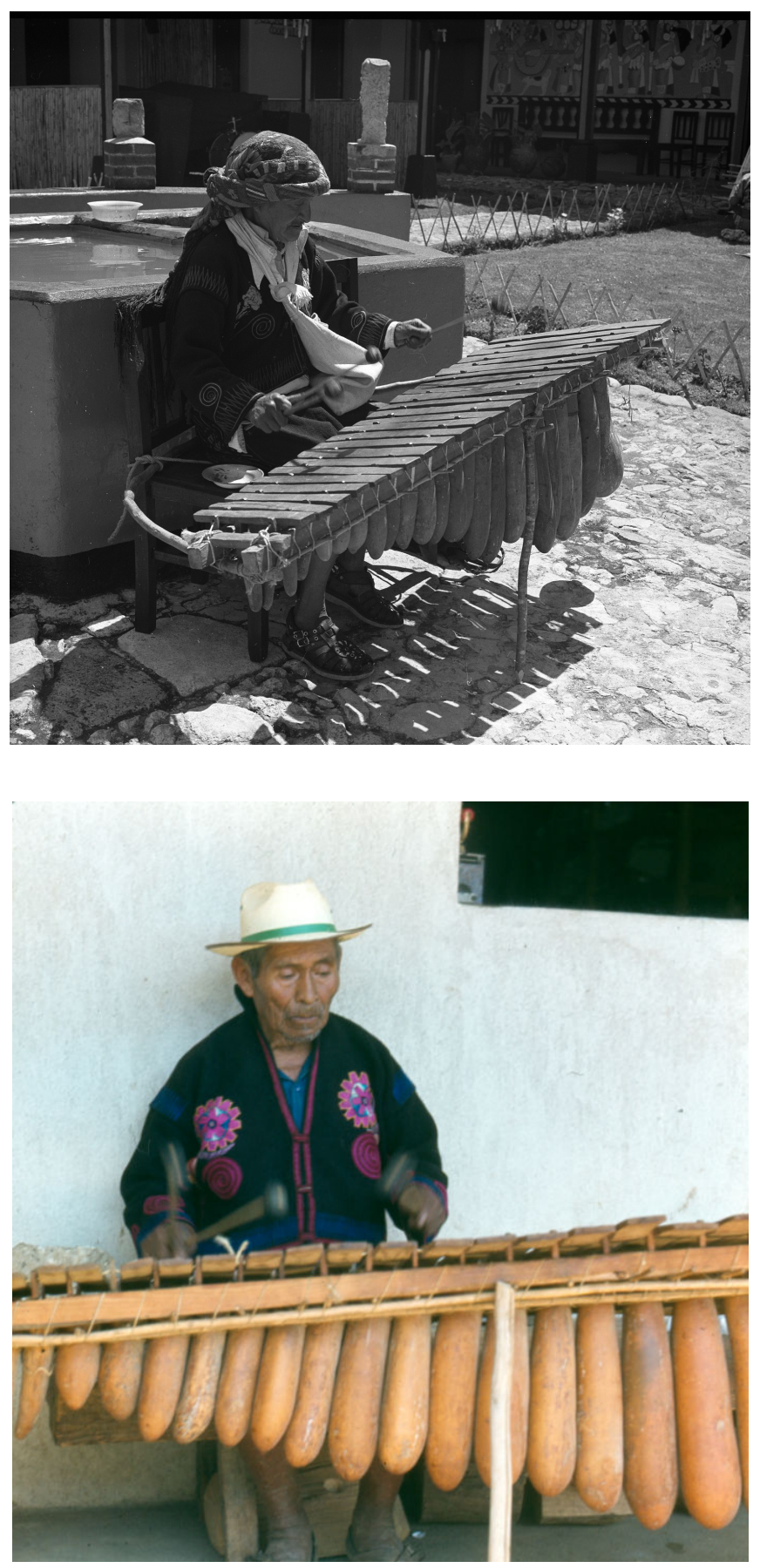

Figure 1. K'iche' musicians playing a k'ojom, a marimba de tecomates (gourd marimba), in Chichicastenango, Guatemala. Note the gourd resonators and the evenly spaced single row of the keys. Photograph by Robert Garfias (reproduced with permission). 


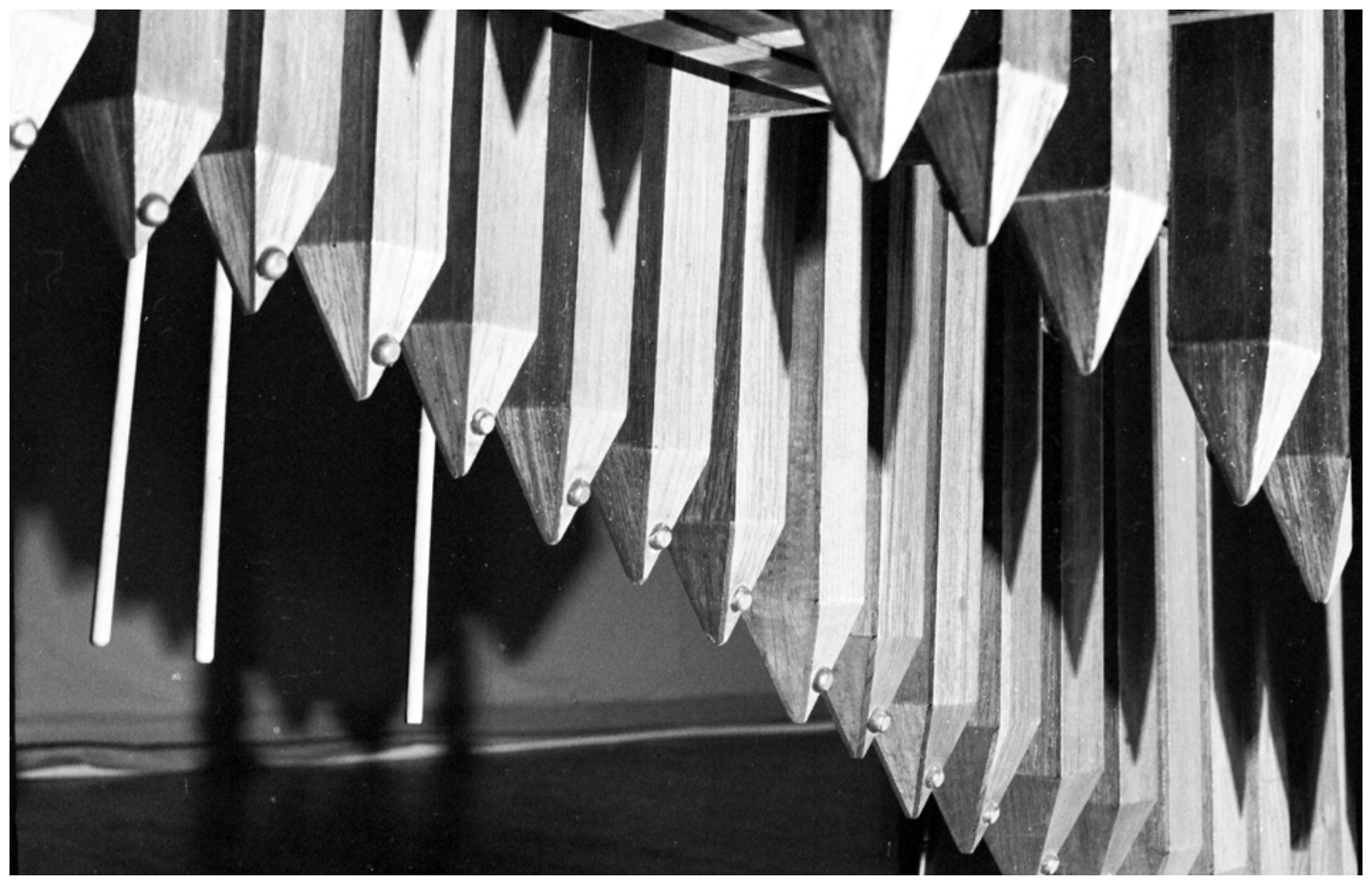

Figure 2. Wooden resonator boxes on a chromatic marimba (chiapaneca).

Photograph by Robert Garfias (reproduced with permission).

Sebastián Hurtado invented the chromatic marimba in Quetzaltenango, Guatemala around 1894 with the conceptual guidance of Julián Paniagua Martínez. ${ }^{17}$ The chromatic marimba has a second row of keys attached to the keyboard (adding five semitone accidentals per octave) thus creating a twelve-note chromatic keyboard. For performances, furthermore, the chromatic marimba is usually played in a two-instrument ensemble-a "marimba doble"-that is comprised of two chromatic marimbas (a large six-octave marimba [played by four musicians] and a smaller three-octave tenor [played by three musicians]).

From a musicological perspective, the development of chromatic marimbas might be described in terms of a technical advance that allows for greater musical versatility. "La evolución de la marimba en Guatemala,” writes Carlos Monsanto, “produjo con el tiempo un verdadero piano de madera “ ("The evolution of the marimba in Guatemala," writes Carlos Monsanto, "produced over time a true wooden piano"). ${ }^{18}$ Godínez maintains that the development of the double chromatic instrument turned the marimba into a more universal instrument. He insists, furthermore, that the marimba

17 Godínez, La marimba guatemalteca, 122. A different type of chromatic marimba was invented in Chiapas, Mexico around 1896 by Corazón de Jesús Borraz. In contrast to Hurtado’s design, the marimba cromática chiapaneca distributes the keys for the accidental notes in a fashion that more closely resembles a piano keyboard. For descriptions of the differences between Guatemalan and Chiapas-style chromatic marimbas see Laurence Kaptain's book, The Wood that Sings: The Marimba in Chiapas, Mexico (Everette: Honeyrock, 1992) and Lester Godínez's La marimba Guatemalteca.

18 Monsanto, "Guatemala a través de su marimba,” 65. 
remains every bit as "Guatemalan" as its precursors. ${ }^{19}$ Though perhaps accurate, this statement invites further inquiry. The chromatic marimba and its precursors may all be "Guatemalan," yet there remain significant distinctions that characterize these instruments on a cultural level.

Whereas Godínez primarily sees the development of the chromatic marimba as a landmark in musical technology, the differences between the marimba doble and its indigenous precursors exceed the realm of mere technical design. In the transformation from k'ojom to "wooden piano," the traditional indigenous instrument was Westernized culturally, technically and materially: "No solo las escalas son europeas, sino también los resonadores llegan a ser de madera, y no del nativo cajón de calabaza. . . Con el tiempo se utilizó el instrumento para tocar obras cien por ciento españolas" ("Not only are the scales European, but they make the resonators out of wood instead of the native gourds .. W With time they started to use the instrument to play pieces that were hundred percent Spanish”). ${ }^{20}$ Indigenous materials and conventions were replaced in the creation of the chromatic marimba and the instrument was used to play European-style music, usually in urban settings.

The technical differences between the marimba de tecomates and the chromatic marimba belie the conceptual distance between the European and indigenous understandings of music. Whereas the marimba de tecomates plays a ritual role in traditional culture, the chromatic marimba is played as an instrument of entertainment, to amenizar (enliven) social gatherings. The national celebration of the chromatic marimba, then, underscores the paradoxical situation that indigenous music occupies within Guatemalan national identity and history.

An analysis of the law declaring the marimba as national symbol reveals a complex discourse that simultaneously celebrates and rejects indigenous culture and music. Decreto (Law) 31-99 makes reference to indigenous culture in the second consideration, asserting a Mayan origin for the marimba and describing the Maya as the indigenous ancestors of Guatemala:

Whereas: The ancestors of the marimba derive from Mayan Culture, an authentic lineage of the ethnic groups of the Guatemalan people, a circumstance that is dignified by this nature and constitutes an expression of national identity, for these reasons it is appropriate to declare the marimba a national symbol. ${ }^{21}$

Speaking for the government, the authors of the law consider the Maya to be the originators of the marimba and the ancestors of contemporary Guatemalans. The Maya are celebrated as the source of the marimba and as the noble roots of Guatemalan identity. The Maya are not, however, acknowledged in this law as playing any importance in contemporary Guatemalan society. Moreover, the third consideration explicitly names the chromatic double marimba, the marimba played by ladinos, as the ultimate representation of the nation: "La marimba de doble teclado con escala cromática constituye la más genuina representación de nuestra nacionalidad" ("The chromatic double

19 Godínez, La marimba guatemalteca, 125. Although I am limiting my discussion to two types of marimba (the indigenous and the chromatic), there exists another diatonic marimba in Guatemala, "la marimba sencilla" (the "simple marimba") which Godínez describes as an intermediate step in the development of the chromatic marimba. The marimba sencilla is also a ladino instrument.

20 Monsanto, "Guatemala a través de su marimba,” 65.

21 "Considerando: Que los ancestros de la marimba se remontan dentro de la Cultura Maya, auténtico linaje de las etnias de pueblo guatemalteco, circunstancia que por su naturaleza la enaltecen, constituyéndola como expresión de identidad nacional, por lo que es conveniente declararla como símbolo patrio.” 
marimba constitutes the most genuine representation of our nationality"). ${ }^{22}$ Where does this leave the Maya with respect to the celebration of Guatemalan music and identity? Specifically, the law places the importance of indigenous culture and music in the past, in the context of the ancestral contributions of the ancient Maya. The instrument glorified as the most genuine representation of Guatemalan culture is not the indigenous k'ojom, but rather the chromatic marimba. The text lauds the chromatic marimba for having improved, and perfected, its indigenous legacy. Dietrich, on the other hand, refers to the chromatic marimba as "la marimba desindianizada, ladinizada" ("deIndianized, mestizo marimba") and reads the national celebration of the chromatic marimba as part of the violence directed at indigenous people. ${ }^{23}$ The subsumption of the k'ojom by the chromatic marimba, in this view, is an instrumental part of the political annihilation of indigenous culture.

How is it possible for an instrument to have so many different meanings? The marimba elicits conflict because of its presence within divergent concepts of identity within Guatemala. For traditional indigenous people, the k'ojom plays a central role in the ritual performances that frame their belief system. For many Ladinos, on the gother hand, the chromatic marimba represents the advance of Guatemalan civilization, the perfect distillation of ancient Mayan roots in a modern (musical) nation. “Conforme el avance de la civilización," writes Marcial Armas, "también la marimba ha avanzado hacia su perfección” (“As civilization has advanced," writes Marcial Armas, "the mariba too has advanced towards its perfection”). ${ }^{24}$ Scholars, furthermore, both from Guatemala and elsewhere, have observed instrumental similarities between marimbas from Africa and the marimba de tecomates. ${ }^{25}$ These similarities-combined with the lack of archaeological evidence of marimbas at Mayan sites and in light of the dates of the first Colonial documents to mention marimbas-imply that African slaves likely introduced the instrument to Guatemalan Indians. The word marimba, furthermore, is believed to derive etymologically from Africa from related terms in the Bantu language group. ${ }^{26}$ From this ethnomusicological perspective, the marimba constitutes a historical case of transculturation that transcends at least two continents (some start the story in Asia) and many different ethnic groups. Ultimately, this spectrum of meanings exemplifies the marimba's polyvalence, as an instrument and as a contested emblem of Guatemalan cultural heritage. From the k'ojom to the marimba doble (chromatic marimba), the instrument has been manipulated and rearranged, musically and discursively, in complex negotiations of ethnic, social, musical and political identities.

\section{Instrumental History: Musical Mestizaje in Maya K'iche' Culture}

Another example of transculturation, this one from contemporary K'iche' culture, illustrates how music and musical instruments continue to play a central role in the process of identity formation for individuals within a postcolonial indigenous community. In Me llamo Rigoberta Menchú y así me nació la conciencia, a text that focuses on individual and community identity, Rigoberta Menchú

\footnotetext{
22 My emphasis.

23 Dietrich, "La marimba," 163.

24 Armas, El renacimiento, 170.

25 See discussions on the evidence for the Guatemalan marimba's African origin in Chenoweth, Garfias, Godínez (La marimba), Monsanto and Navarrete Pellicer.

26 Godínez, La marimba guatemalteca, 34-7 and Navarrete Pellicer, Maya Achi Marimba, 70-74.
} 
describes the process in which music embodies both the Catholic and indigenous sides of her identity: "Nuestra reunión cultural como indígenas, la teníamos el viernes. Nuestra reunión como católicos, el lunes" ("We had our cultural meeting as indigenous people on Fridays. Our meeting as Catholics on Mondays"). ${ }^{27}$ She describes her connection to indigenous musical instruments as a vehicle through which to become a part of her people by invoking the ancestors in the presence of her family: "And so this was when I became so interested in learning to play the instruments of our ancestors. For example, the tún, the drum, the sijolaj, which we still have, the chirimía. ${ }^{28} \mathrm{We}$ started to practice with my siblings." 29 Menchú emphasizes the fact that the traditional music shared amongst her family is a crucial link to their past. Music functions as a kind of cultural glue that solidifies the family both within their immediate community and within their place in history. Their instruments are not merely tools with which to produce specific sounds, the instruments embody traditional connections to their ancestors. Menchú's interest in learning to play the traditional instruments points to a cultural need to repeat the rituals of her ancestors on her ancestors' instruments: "Me interesé . . en aprender a tocar los instrumentos de nuestros antepasados" ("I became interested . . . in learning to play the instruments of our ancestors"). ${ }^{30}$ Playing their sacred music on ancestral instruments and perpetuating their mythology, Menchú describes contemporary K’iche' Indians employing music as a ritual of (traditional) cultural reproduction.

Although Menchú mentions the chirimía as a traditional instrument of her ancestors, Spaniards actually introduced this (oboe-like) double-reed aerophone in colonial Central America and Mexico. In other words, the chirimía may be an instrument of her ancestors, though not her pre-Columbian indigenous ancestors. According to Schechter and Stobart, the chirimía is still played in Spain, in Santiago de Compostela, Salamanca and Galicia in processional marches. In Mexico it is often played from a church tower. Chirimía and drum ensembles accompany the Baile de la Conquista (Dance of the Conquest) in Guatemala. The chirimía may in fact have Arabic roots, which date from the long Moorish occupation of the Iberian Peninsula. ${ }^{31}$

Menchú also describes her community as one that knows and sings Catholic songs: "Rezábamos como católicos con los vecinos a la vez, tocando nuestros instrumentos" ("We prayed as Catholics

27 Elizabeth Burgos, Me llamo Rigoberta Menchú y así me nació la conciencia (Mexico: Siglo XXI, 1988), 111.

28 The tún (also called c'unc'un or tuncul, known by the Aztecs as teponaxtli) is a hollow wooden slit-drum (idiophone).

Striking the H-shaped tongues creates two different tones. In 1924, in a chapter entitled "La organografía prehistórica de los indígenas,” Luis Castillo affirms that the tún is the most important instrument of Mesoamerican Indians (71-7).

The sijolaj (tzijolaj, also called $z u$ or $x u l$ [in Spanish pito]) is a three- or sometimes four-hole open duct cane flute (aerophone). According to Jesús Castillo the tzijolaj is the second most important instrument for the Maya K'iche'. It is played for sacred music. Castillo informs that the term tzijolaj translates as "Elevador de las Oraciones” (a "prayer elevator") (78-84).

The chirimía (xirimía) is a shawm, an oboe-like aerophone that was introduced by the Spaniards. There exist a number of different types of chirimía throughout Latin America. For description of varieties of chirimía in Mexico, Guatemala and Colombia, see Joan Rimmer's 1976 article, “The Instruments called Chirimía in Latin America.”

29 Burgos, Me llamo Rigoberta Menchú, 111. “Así es cuando yo me interesé tanto, tanto en aprender a tocar los instrumentos de nuestros antepasados. Por ejemplo, el tún, el tambor, el sijolaj, que todavía conservamos, la chirimía. Empezábamos a practicar con mis hermanos.”

30 Ibid. Italics mine.

31 Joan Rimmer, "The Instruments called Chirimía in Latin America,” Studia Instrumentorum Musicae Popularis 4 (1976): 110 and Dieter Lehnhoff, Creación musical en Guatemala (Guatemala: Editorial Galería Guatemala, 2005), 226. 
with our neighbors, while at the same time, playing our instruments"). ${ }^{32}$ [111]). Music from indigenous, Catholic and Islamic traditions combines in Menchú's community to form a postcolonial fusion. Her family plays ancestral instruments while praying as Catholics. Music delineates the divisions and junctures between the Catholic and indigenous aspects of her life, history and her community at large. Music does not represent either the indigenous or Catholic side of Menchú's culture unilaterally, it engages, rather, in a process of negotiation. Musical mestizaje (blending) shapes and contours this postcolonial Guatemalan community.

Although Catholicism and traditional culture shape the foundations of contemporary K'iche' identity, our reading would be far too narrow if it were limited to this binary paradigm. In order to more fully understand the negotiation and location of culture, the factor of popular music needs to enter into the equation. In many communities, the pressures of Western culture and popular music are proving corrosive to native traditions in Guatemala and throughout Indo America. At the same time, the roots of indigenous culture remain inextricably bound within mestizo popular music. The precise historical origin of the marimba may remain a mystery, but clearly the indigenous k'ojom played a foundational role in the development of the chromatic marimba. Conversely, indigenous people also appropriate elements of mestizo music and retool them, paradoxically creating new versions of "traditional" music. Navarrete Pellicer sums up this process in four words: "New music, old meanings." 33 The relationship between indigenous and Hispanic music, then, is not a linear progression of historical influence, but rather a complicated web of transcultural interactive feedback. Reading the patterns of "give and take" helps to reveal the ways in which music and musical instruments mediate the negotiations of indigenous and mestizo identity.

\section{Tzotzil Music from Chiapas: Traditional Music as Cultural Compass}

The conflictive relationship between traditional indigenous and contemporary popular music in Mexico is a central theme in the Chiapas Media Project (CMP)/Promedios video, Song of the Earth: Traditional Music from the Highlands of Chiapas (2002).$^{34}$ In this indigenous-produced documentary, a group of Tzotzil musicians from San Andrés Sakamch'en lament the fact that young people today tend to reject their traditional music, dances and clothing. "Who will be there?" asks one elder, "to receive the memory and words of our fathers and mothers?" By posing this question he is in effect formulating a plausible definition of "music" from an indigenous perspective. Throughout time and in various cultures, we see a conception of traditional music and dance as "the memory and words of our fathers and mothers."

The musicians in Song of the Earth play for members of the EZLN (Ejército Zapatista para la Liberación Nacional / The Zapatista National Liberation Army) communities as well as a general public. In spite of their obvious political affiliation, their music does not convey an inherently

32 Burgos, Me llamo Rigoberta Menchú, 111.

33 Navarrete Pellicer, Maya Achi Marimba, 166.

34 The Chiapas Media Project/Promedios, founded by documentary video producer Alexandra Halkin in 1998, gives technical training and video equipment to indigenous (and campesino) peoples from the Mexican states of Chiapas and Guerrero. The goal of the CMP/Promedios is to provide indigenous people with the tools and means possible to represent themselves in their own indigenous-made video documentaries. The $\mathrm{CMP} /$ Promedios now has a long list of video documentaries available. See the Chiapas Media Project/Promedios web page: http://www.promedios.org 
political message. The music is not intended to broadcast outside of their community. This is not a political movement that attempts to carry their message throughout the world via music. Rather, these are indigenous peoples experiencing their own music within their own community. Even the video was produced in part to serve the community, "to help foster dialogue about why the youth are not learning traditional music or wearing traditional clothing." ${ }^{35}$ In a sense, this conception of music approximates that of Rigoberta Menchú's testimonial. As was the case described by Menchú, the music of Highlands Chiapas produces cultural cohesion within the community. ${ }^{36}$ What is different here is that the Tzotziles describe their traditional music as culture under siege, in conflict with popular music.

For the Tzotzil musicians, the survival of their music will ensure the endurance of their traditional culture: "The wisdom of the hearts and minds of our ancestors has not been lost; it continues to live on through us in our music, dances and languages." Here again we see the indigenous view of music as the embodiment of ancestral cultural knowledge. Ironically, the Spanish title of the video-Son de la tierra-conveys through its multiple meanings the relation between music and culture as represented by the indigenous world view. "Son" means "sound" and "song" and simultaneously reads as the conjugation of the verb "to be." Son de la tierra, in other words, conveys the role that music plays in designating the cultural location and identity of a people and their community. Son de la tierra can be translated as either "Song of the Earth" or "They come from the Earth." To locate Tzotzil culture we can read their music, paying special attention to the places where Hispanic and indigenous sound cultures converge and diverge with and from one another, historically, and in response to contemporary popular music.

It would be naïve and erroneous to assume that Tzotzil culture and music would have remained static for centuries. Some of these changes are immediately evident in their clothing. The musicians wear traditional Tzotzil clothing with Zapatista masks, bandanas and sometimes cowboy hats. Obviously, myriad details have affected Tzotzil culture and music since the time of the Conquest. As is clear from earlier discussion, music became a focal point of transcultural negotiation early in the colonization. The crosses in the procession of San Andrés highlight syncretic elements of contemporary Tzotzil culture. Whereas they speak of their "true music" and "traditional instruments," Western culture has contributed to shape present-day Tzotzil traditions. The musical instruments that they play underscore this process. Although the instruments we see in the video are obviously hand hewn, the presence of harps, guitars and violins indicates the influence of Spanish culture in their music.

\section{Hybrid Instruments / Hybrid Roots}

At some time in history the Tzotziles chose to adopt European instruments and adapted them to produce "traditional" indigenous music. Are they playing European instruments? One could argue

35 Alexandra Halkin, personal electronic communication (July 29, 2005).

36 Whereas they create music in and for their own communities, Menchú's testimonial and the CMP/Promedios video documentary do also operate, as texts, on an international level. Both Me llamo Rigoberta Menchú and Song of the Earth were conceived of with the goal of global dissemination in order to sensitize the international community to the social and political situations of indigenous peoples in Guatemala and Chiapas, Mexico. 
that some instruments played by native peoples only resemble superficially their European prototypes. Ethnomusicologist Samuel Martí observes that some indigenous guitars and violins look like European instruments, but they have been designed to produce different sounds: "Huichol, Tarahumara, or Chamula guitars or violins may look like their sixteenth-century forebears, but it is practically impossible to play European music on them, since their makers have only their own music in mind in their tuning and construction." ${ }^{37}$ Godínez, in a similar vein, asserts that in light of different construction processes, materials and playing techniques, the European-style instruments played by Indians are in essence indigenous: "Dichos instrumentos conservan sólo la apariencia ajena pero en el fondo ya son enteramente indígenas" ("Said instruments only conserve a foreign appearance, in essence they are entirely indigenous"). ${ }^{38}$ Accordingly, the Spaniards introduced concepts of certain musical instruments that the Indians customized over time depending on their own needs and preferences. Most likely, the modifications were not carried out consciously; they have occurred over hundreds of years of cultural and musical mestizaje.

An interesting research project would be to examine handmade indigenous harps, violins, guitars and other European-style instruments to determine how the designs might have been modified to produce a more indigenous sound..$^{39}$ Questions of relative pitch and tuning would be central to such a study. Salvadoran composer Arturo Corrales comments that mestizos often think that indigenous music sounds out of tune: "When you go hear the indigenous people playing, you say: 'this Indian sounds out of tune.' But, out of tune in relation to what? Who invented the notes, the scale, why do, re, mi? The criteria are completely cultural." ${ }^{40}$ Preferences in sound quality and tuning are entirely cultural and psychological. ${ }^{41}$

The sounds produced by the Guatemalan marimba de tecomates (k'ojom) also illustrate the cultural determination of sound preferences and tuning. The marimba de tecomates takes its name from a series of resonating gourds (tecomates) that hang down from the keys. The instrument-maker perforates each gourd with a special hole, surrounds it with a mound of black wax, and then forms a seal with a membrane made from the intestine of a female pig. The ensemble of hole, wax ring and membrane is called the mush, meaning belly button in K'iche' and Kaqchikel. The mush produces

37 Samuel Martí and Gertrude Prokosch Kurath, Dances of Anáhuac: The Choreography and Music of Precortesian Dances (Chicago: Aldine Publishing Company, 1964), 187.

38 Lester Godínez, "Panorámica de la música autoctona de Guatemala," Cultura de Guatemala, Segúnda época 16, no. 4 (September - December 1995): 28.

39 For a study of the indigenous adaptation of the harp in South America, see John Mendell Schechter's, The Indispensable Harp: Historical Development, Modern Roles, Configurations, and Performance Practices in Ecuador and Latin America (Kent, Ohio: Kent State UP, 1992).

40 “Cuando vas a oír a los indígenas tocando, vos decís: 'es que el indito suena desafinado.' Pero ¿desafinado en relación a qué, quién inventó las notas, la escala, por qué do, re, mi? Son criterios completamente culturales.” From an interview with Arturo Corrales, "Plática con Arturo Corrales, músico salvadoreño, arquitecto de sonidos" by Ruth Grégori and José Ángel Mejía. The interview can be accessed on line at Elfaro.net, http://www.elfaro.net/Programas/Buscar/DetalleNota.php?IDNota=2575

41 Psychologist Daniel J. Levitin defines "pitch" as a psychological phenomenon: "Pitch is a purely psychological phenomenon related to the frequency of vibrating air molecules. . . . It is entirely in our heads, not in the world-outthere; . . . Sound waves-molecules of air vibrating at various frequencies-do not themselves have pitch. Their motion and oscillations can be measured, but it takes a human (or animal) brain to map them to that internal quality we call pitch" (21). Levitin defines "scales" as arbitrary elements of musical systems that are selected and defined by culture: "A scale is just a subset of the theoretically infinite number of pitches, and every culture selects these based on historical tradition or somewhat arbitrarily" (27). 
the characteristic buzz that is often cited as evidence of the African roots of the marimba. ${ }^{42}$

Non-Indians often observe that the marimba de tecomates, sounds "out of tune." Dietrich, on the other hand, questions whether the range of the instrument can accurately be described with the Western diatonic scale. He posits that Western listeners hear an "out of tune" diatonic scale because of their cultural predisposition to hear music in relation to occidental scales. In Dietrich's view, the k'ojom obeys a different, intentionally determined, musical order: "Clearly contemporary musicians and communities require the particular sound of their k'ojom. The Mayan priests insist on maintaining the 'erroneous' tuning of the instrument and musicians reproduce this with great care."3 If this is true, the marimba de tecomates is not out of tune, its construction, rather, corresponds to a different system or cultural logic. Dietrich points out that the tuning of each k'ojom conforms to the preferences of the musician and his community. These instruments are not even compatible between two Mayan communities, much less international tuning conventions. As further evidence of uniquely indigenous tuning systems, Dietrich cites interviews with Maya school teachers who insist that they cannot play their traditional music on chromatic marimbas: "Esas piezas no suenan en la marimba doble, son intocables" ("Those pieces don't come out on the double marimba, they are not playable"). ${ }^{44}$ The music created by indigenous musicians is produced in accordance with native cultural tastes and criteria-cultural preferences that represent underlying hybrid roots.

\section{A Hybrid Violin: The Paradox of the Original}

Often, we can see the hybrid roots of indigenous culture in musical instruments. Jorge Luis Acevedo's La música en las reservas indígenas de Costa Rica includes a photo of an indigenous violin with a commentary by Térraba musician/luthier, Mamerto Ortiz Ortiz (1982). The list of woods he uses (Guanacaste de montaña, Guayacán, Guachipelín) would surprise a European violin-maker, not to mention the fact that he strings the instrument with guitar strings. Ortiz Ortiz uses his violin to play both traditional music and contemporary popular songs: "Con el violín toco mucha música de mis padres y abuelos, también puntos y cumbias" ("With the violin I play a lot of my parents' and grandparents' music, also puntos and cumbias"). ${ }^{45}$ This transcultural instrument derived from an essentially virtual source. Ortiz Ortiz explains that he "copied the shape of the violin from a newspaper photograph over fifty years ago" ("La forma del violín la copié de una foto del periódico de hace más de cincuenta años”). ${ }^{46}$ Tracing the origin of this hybrid instrument back to a photograph leads to an image of a copy of a European violin. This is reminiscent of Derrida's reading of language: A system comprised of signs that always point to other signs (these, in turn, signifiers of other signifiers) rather than an original referent. Such is our quest for origins in culture, history and music.

42 Godínez, La marimba guatemalteca, 108.

43 Dietrich, "La marimba," 157. "Es evidente que hasta el día de hoy los músicos y las comunidades requieren el sonido particular de su k'ojom. Los sacerdotes mayas insisten en mantener la afinación 'errónea' del instrumento y los músicos la reproducen con sumo cuidado.”

44 Ibid., 185.

45 Jorge Luis Acevedo V, La música en las reservas indígenas de Costa Rica (San José: Editorial de la Universidad de Costa Rica, 1986), 78. Listen to a recording of Mamerto Ortiz playing "Cumbia Antigua Térraba," (track \#6) of Jorge Luis Acevedo's compact disc, Música indígena costarricense.

46 Ibid. 
This history of a Térraba violin recalls the example of Guatemalan Indians and the manner in which they refer to the manuscripts of their dance-dramas. The Baile de la Conquista (Dance of the Conquest), for example, developed from various versions of the drama from the area of Quetzaltenango that date from the mid to late 1800's. The written manuscript is treated with the utmost reverence and respect, it serves as the immediate reference for the drama and is crucial, even when teaching spoken lines to illiterate participants. These manuscripts are usually referred to as " $\mathrm{el}$ original" ("the original"). Folklorist Barbara Bode reports (from her field work in 1957) that when a manuscript becomes worn or faded, an "autor" (author) re-copies the text (often introducing errors, other times intentionally modifying the text) and this latest manuscript then becomes the new "original." ${ }^{47}$ For the Baile de la Conquista, then, "original" does not signify the "first" text, but rather the definitive, most useful and most recent copy. We might follow this example when talking about the Térraba violin. Granted a European violin (and many subsequent copies) existed "first," but in light of the modifications we could say that Ortiz Ortiz's copy of a photo of a copy of an instrument actually constitutes a new indigenous instrument, in other words, a new "original." Indigenous instrument makers from throughout the Americas, furthermore, have crafted new originals by refining European copies according to their own autochthonous criteria.

\section{Some Contemporary Mestizo Innovations on Indigenous Instruments}

If indigenous instrument-makers create new "originals" by remaking European copies, the process comes full circle in the case of mestizos who use indigenous instruments and music to assemble new musical innovations. Guatemalan composer Joaquín Orellana Mejía has designed an extraordinary series of new musical instruments-"útiles sonoros" ("sonorous tools")-most of which derive from the marimba. ${ }^{48}$ The names of Orellana's "acoustic tools" tend to fuse fragments of the word "marimba," with the sounds and shapes of his designs. His first design, the sonarimba, is a hollow bamboo canister that is fitted with wooden marimba keys at the top and bottom. A small plastic ball inside the canister creates sound when a musician shakes the instrument. The name, sonarimba, poetically fuses the names of two instruments (sonaja [rattle] and marimba) with the musical sound/rhythm, son. Whereas the name sonarimba evokes two instruments, simultaneously playing a group of sonarimbas produces a collage-like effect of multiple marimbas.

The names of Orellana's útiles sonoros might be considered short poems that produce visual images of their musical properties. Orellana's imbaluna curves a marimba keyboard upwards to form the shape of a crescent moon. In this case, the name imbaluna superimposes marimba and the moonlike shape of Orellana's musical sculpture. The circumar (a large circle of suspended marimba keys)

47 Barbara Bode, "The Dance of the Conquest of Guatemala," in The Native Theater in Middle America (New Orleans: The Middle American Research Institute of Tulane University, publication No. 27, 1961), 227.

Caroll Edward Mace also reports that the texts of Guatemalan Bailes are known as "originales" (85). According to Bode the other most common term is "la historia" (the history) though the texts are also called "la relación" (the story) "el libro" (the book) and "el manuscrito" (the manuscript) (220).

48 For partial lists of Orellana's útiles sonoros with photographs, see the catalog of the museum show, Sinfonía delirante, in the Museo Nacional de Arte Moderno/ Guatemala in 1998. See also the section on Orellana in Godínez's La marimba guatemalteca (266-72) and the interview (by Ingrid Roldán Martínez ), "Orellana y su marimba fantástica” (http://www.prensalibre.com/pl/domingo/archivo/revistad/2004/noviembre04/141104/dfrente.shtml). 
reiterates the circular shape of the instrument (and the circular relation between music and musical instruments) in its nomenclature. The circumar first alludes to the instrument's circular form and follows with the beginning of the name marimba.

Another of Orellana's "musical tools," the "Ciclo Im," bends the marimba even farther, turning the marimba into the shape of a cylindrical wheel. The Ciclo Im contains a small ball that produces sound by striking the keys when the instrument is spun. We might visualize this acoustic toolinstrument-sculpture as a marimba turned inside out. Not only are the sound-producing surfaces of the keys located on the inside, the playing technique also inverts the traditional role of the musician.

To play marimba a marimbista strikes mallets against the keys to produce sound. To play a Ciclo Im, on the other hand, the musician spins the keys. Turning the cylinder moves the keys around the ball, which then moves via momentum and produces music. Metaphorically, we might say that Orellana's work similarly inverts the traditions of Western instruments and music. By perpetually rearticulating inverted pieces of marimbas, Orellana develops original compositions of contemporary classical music.

\section{Audio Example 2}

Accessible at: http://dx.doi.org/10.3998/mp.9460447.0001.202

Description: "Ramajes de una marimba imaginaria" by Joaquín Orellana. Interpreted by the Marimba Nacional de Guatemala under the direction of Léster Godínez. The piece is performed on útiles sonoros (sonorous tool), concert marimba and the voice of a narrator.

Both the instruments (útiles sonoros) and his music have roots in indigenous culture. Orellana's work, moreover, generates a serious dimension of political critique. In an interview with Ingrid Roldán Martínez, Orellana explains that many of his compositions echo the sounds of indigenous suffering at the hands of the Guatemalan armed forces. Of his 1998 composition, "Sacratávica," for example, Orellana comments that the structure contains a son de la muerte, a death song: "Tiene dentro de su estructura un son de la muerte, un son doloroso acompañado por un ritual vocal bastante libre que evoca los entierros o la estupefacción ante los cementerios clandestinos" ("The composition has within its structure a death song [son], a painful song that is accompanied by a fairly free vocal ritual evoking burials or the awe provoked by clandestine cemeteries"). ${ }^{49}$ Through his sonorous experiments with indigenous sounds (both the phonemes of indigenous languages and the marimbabased elements of indigenous music), Orellana denounces the violent abuse inflicted against Indians in Guatemala, and rearticulates an idiophone in defense of indigenous people. In this way, Orellana's marimba-based music and útiles sonoros "strike back" at the musical and political status quo. ${ }^{50}$

49 Interview with Roldán Martínez.

50 The seriousness of Orellana's political stance becomes clear in anecdotes described in the interview with Roldán Martínez. His 1992 composition, Cerros de Ilom, was blacklisted by the government. Orellana explains that at that time he feared assassination: "Yo sí sentía que de repente iba a sonar la ráfaga" ("I felt like all of a sudden there would sound a burst from a machine gun”). 


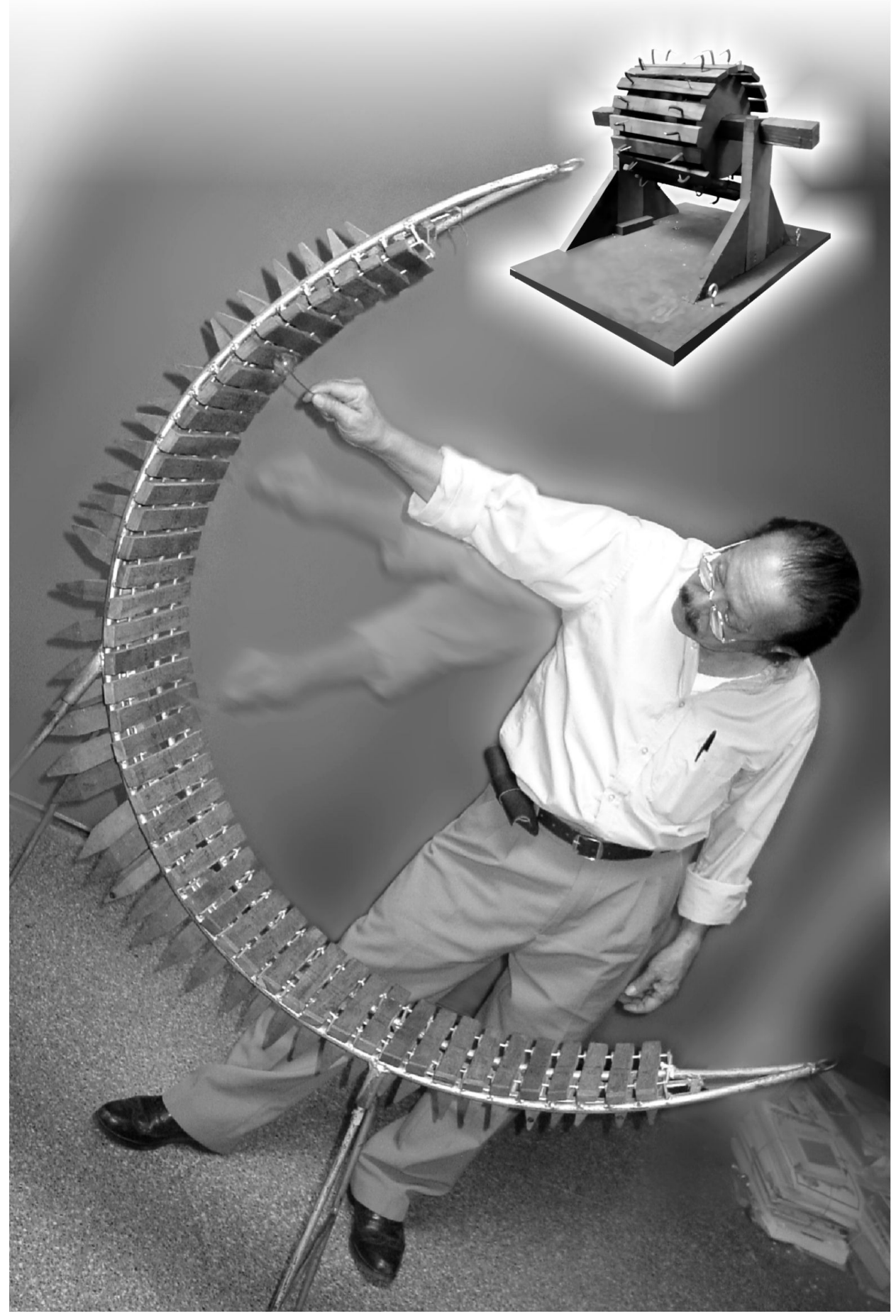

Figure 3. Joaquín Orellana playing his imbaluna (with his Ciclo Im in the upper right corner). Photo by Diana de Arango. 


\section{Conclusion}

The development of hybrid instruments is part of an on-going process of transculturation and this essay has highlighted a few noteworthy examples. Spanish priests brought the Islamic-derived chirimía to the New World and the Indians converted it into a traditional indigenous instrument. For Rigoberta Menchú, the chirimía is as traditional as is the tún and the sijolaj. Other indigenous groups, such as the Tzotzil of Highlands Chiapas, indigenized European instruments (guitars, harps and violins) according to their own cultural needs and preferences. Similarly, Ortiz Ortiz's violin can be read as an original indigenous instrument that derives from an uncertain European origin, a photograph of a copy, and functions as a 'traditional' Térraba artifact.

Orellana's instrumental innovations effectively re-start the process of cultural renovation at a different location in the cycle. Orellana designs and creates new indigenous-derived instruments. These new instruments are crucial for the representation of their original musical compositions. These instruments, moreover, re-present the marimba (an indigenous instrument of uncertain origin) and in so doing produce new mestizo "originals." ${ }^{51}$ The historical trajectory of the marimba-from indigenous instrument of unknown origin to chromatic national symbol of (Ladino) Guatemala, and then to Orellana's util sonoro (a mestizo invention that denounces the repression of indigenous people)-highlights the transcendence of indigenous musical culture and also its plasticity as an artistic and political discourse.

Reading indigenous and mestizo instruments reveals many of the lines along which identity has been negotiated and played out across history in Latin America. By exploring these cultural and political negotiations we can obtain a clearer view of the complex, transcultural compositions that characterize and define Latin America.

51 I should clarify that Orellana has also developed instruments that are not based on the marimba. This said, Orellana bases most of his útiles sonoros and compositions on the marimba. Musically, his compositions are noticeably experimental (avant garde/ modern classical). 


\section{Works Cited}

Acevedo V, Jorge Luis. La música en las reservas indígenas de Costa Rica. San José: Editorial de la Universidad de Costa Rica, 1986.

—. Música indígena costarricense. CD. Centro de Documentación e Investigaciones Artísticas, 2003.

Anléu Díaz, Enrique. “Apuntes sobre el origen de la marimba.” Tradiciones de Guatemala 43 (1995).

Armas Lara, Marcial. El renacimiento de la danza guatemalteca y el origen de la marimba. Guatemala: Centro Editorial "José de Pineda Ibarra," 1964.

Asturias Gómez, Carlos Ramiro and César Pineda del Valle. Eds. Antología de la marimba en America / La verdadera evolución de la marinbah maya. Guatemala: Artemis-Edinter, 1994.

Bode, Barbara. "The Dance of the Conquest of Guatemala." The Native Theater in Middle America. New Orleans: The Middle American Research Institute of Tulane University, publication No. 27, 1961.

Burgos, Elizabeth. Me llamo Rigoberta Menchú y así me nació la conciencia. Mexico: Siglo XXI, 1988.

Castillo, Jesús. La música maya quiche. Guatemala: Editorial Piedra Santa, 1981.

Chenoweth, Vida. The Marimbas of Guatemala. Lexington: U of Kentucky P, 1964.

Corrales, Arturo. "Plática con Arturo Corrales, músico salvadoreño, arquitecto de sonidos.” Interview. Ruth Grégori and José Ángel Mejía. Elfaro.net. http://www.elfaro.net/Programas/Buscar/DetalleNota.php?IDNota=2575

Dietrich, Wolfgang. "La marimba: Lenguaje musical y secreto de la violencia política en Guatemala.” América Latina Hoy 35 (203): 147-66.

Garfias, Robert. "The Marimba of Mexico and Central America." Latin American Music Review/Revista de Musica Latinoamericana. 4, no. 2 (1983 Fall-Winter): 203-228.

Godínez, Lester. La marimba guatemalteca. Fondo de Cultura Económica, 2002.

—_. "Panorámica de la música autoctona de Guatemala." Cultura de Guatemala, Segúnda época 16, no. 4 (September - December 1995): 7-65.

Lehnhoff, Dieter. Creación musical en Guatemala. Guatemala: Editorial Galería Guatemala, 2005.

Levitin, Daniel J. This is Your Brain on Music: The Science of a Human Obsession. New York: Dutton, 2006.

Mace, Carroll Edward. “Algunos apuntes sobre los bailes de Guatemala y de Rabinal.” Mesoamérica 2 (1981): 83-136.

Martí, Samuel and Gertrude Prokosch Kurath. Dances of Anáhuac: The Choreography and Music of Precortesian Dances. Chicago: Aldine Publishing Company, 1964.

Monsanto, Carlos. “Guatemala a través de su marimba.” Latin American Music Review 3, no. 1 (SpringSummer 1982): 60-72.

Navarrete Pellicer, Sergio. Maya Achi Marimba Music in Guatemala. Philadelphia: Temple UP, 2005.

Orellana, Joaquín. Interview. “Orellana y su marimba fantástica.” Ingrid Roldán Martínez. Revista D. Semanario de Prensa Libre. 19. Nov. 14, 2004. On-line:

http://www.prensalibre.com/pl/domingo/archivo/revistad/2004/noviembre04/141104/dfrente.shtml 
Rimmer, Joan. "The Instruments called Chirimía in Latin America.” Studia Instrumentorum Musicae Popularis 4 (1976): 101-110.

Schechter, John M. and Henry Stobart. “Chirimía.” Grove Music Online. ed. L. Macy. (Accessed 3/13/05) http://www.grovemusic.com

Schechter, John Mendell. The Indispensable Harp: Historical Development, Modern Roles, Configurations, and Performance Practices in Ecuador and Latin America. Kent, Ohio: Kent State UP, 1992.

Song of the Earth: Traditional Music from the Highlands of Chiapas. Videocassette. Chiapas Media Project, 2002. 